\author{
Andrzej Klasik \\ Florian Kuźnik
}

\title{
Regiony wobec wyzwań przyszłości
}

\section{Streszczenie}

Celem opracowania jest włączenie kategorii pojęciowej „wyzwania przyszłości” do procesu kreowania przyszłości regionów. Artykuł ma charakter refleksji metodologicznej na temat miejsca wyzwań w myśleniu o przyszłości i kreowaniu przyszłości. Zwrócono uwagę na centralne miejsce wyzwań przyszłości w procesie tworzenia strategii i zarządzania regionem. Omówiono rolę wyzwań w pracach diagnostycznych, studiach foresightowych oraz w planowaniu strategii regionów. Artykuł powstał na podstawie doświadczeń eksperckich i doradczych autorów.

Słowa kluczowe: wyzwania przyszłości, przyszłość regionów, regionalny governance, wizje regionów, gra o przyszłość regionów.

Klasyfikacja JEL: R58, O11, R11.

\section{Wprowadzenie}

W opracowaniu podjęto cztery zasadnicze wątki tematyczne. Pierwszym z nich są wyzwania przyszłości, które uznano za myśl przewodnią dla całości prowadzonych rozważań. Zdaniem autorów, potwierdzonym własnym doświadczeniem studiów foresightowych i analiz strategicznych, wyzwania przyszłości kształtują myślenie o przyszłości i kreowanie przyszłości [Klasik i Kuźnik 2013]. Drugi wątek stanowi kwestia przyszłości regionów rozpatrywana w kontekście stylu

Andrzej Klasik, Uniwersytet Ekonomiczny w Katowicach, Wydział Ekonomii, Katedra Badań Strategicznych i Regionalnych, ul. 1 Maja 50,40-287 Katowice, e-mail: andrzej.klasik@ue.katowice.pl Florian Kuźnik, Uniwersytet Ekonomiczny w Katowicach, Wydział Ekonomii, Katedra Badań Strategicznych i Regionalnych, ul. 1 Maja 50,40-287 Katowice, e-mail: florian.kuznik@ue.katowice.pl 
rządzenia określonego mianem governance. Zamiarem autorów jest położenie akcentu na przywództwo strategiczne władzy publicznej w procesie współrządzenia i współzarządzania regionem i w regionie. Trzeci wątek to analiza interakcji wizji regionów z wyzwaniami przyszłości. W opracowaniu ukazano z jednej strony to, że wizje regionów są kształtowane przez wyzwania intelektualne będące rezultatem prac diagnostycznych, a z drugiej, że wizje regionów będące wytworem foresightu przez wyzwania strategiczne kształtują strategie regionów. Ostatnim wątkiem jest gra o przyszłość regionów rozgrywana w układzie różnych grup interesariuszy w ramach mechanizmów: rynkowego, regulacyjnego i społecznościowego. Kategoria wyzwań przyszłości ułatwia integrację wymienionych mechanizmów, tworząc platformę umożliwiającą wychodzenie przywództwa regionalnego z inicjatywami strategicznymi. Połączenie, krok po kroku, zawartych w opracowaniu wątków tematycznych w nowym świetle ukazuje rangę wyzwań przyszłości i w nowy sposób czyni spójnym postępowanie diagnostyczne, foresightowe i strategiczne.

\section{Wyzwania przyszłości}

Wyzwania są terminem, który na stałe wszedł do języka środowisk intelektualnych, zespołów eksperckich i gremiów przywódczych. Współcześnie posługują się nim badacze, wizjonerzy i politycy. Wyzwania stały się kluczowym słowem występującym w tytułach raportów i publikacji, a także pojawiają się jako ważny termin w dyskusjach na różnych forach i w wystąpieniach. Są słowem stosowanym w celu zaznaczenia ważności treści przekazu. Można również stwierdzić, że słowo to jest nieraz używane bezrefleksyjnie, w przypadkowych kontekstach, co jest przejawem swego rodzaju mody.

Dochowując wierności treści, którą niesie termin „wyzwanie”, warto przywołać dwa jego znaczenia [Słownik języka polskiego... 1985, s. 868]. Z jednej strony, wyzwania są tym, czemu trzeba sprostać, czemu trzeba podołać, aby przetrwać lub nadążać za zmianami. $Z$ drugiej strony, wyzwania ukazują to, co warto podjąć, z czym i z kim warto się zmierzyć, aby iść do przodu i rozwijać się. W pierwszym przypadku to my stoimy przed wyzwaniami, w drugim zaznaczają się nasze aspiracje; możemy podejmować i rzucać wyzwania.

Wyzwania jako znaczący koncept uzyskały wysoki status i nadaje się im wysoką rangę dla wyrażenia konkluzywnych stwierdzeń, dla finalnego ujęcia efektów szeroko zakrojonych, wielotematycznych i interdyscyplinarnych studiów, ekspertyz i diagnoz. Posłużenie się tym konceptem jest równie ważne dla dokonania i zakreślenia nowego otwarcia w jakiejś dziedzinie lub uruchomienia nowego kierunku myślenia, badań czy projektów. Może to stanowić początek 
i zalążek czegoś nowego na gruncie różnych obszarów i dziedzin wiedzy, sztuki i polityki. Wyzwania jako koncept służą odkrywaniu, dostrzeganiu i wskazywaniu nowych pól decyzyjnych, kierunków zmian oraz zbiorowych akcji i działań.

Wysoki status i ranga wyzwań tkwią w treści, które one niosą. Zawarte w nich idee kierują myśli ku przyszłości zarówno w sensie intelektualnym, jak i w sensie pierwszoplanowych, strategicznych rozstrzygnięć. W niniejszych rozważaniach oznacza to ukierunkowanie myśli, decyzji i akcji ku przyszłości regionów. Wyzwania przyszłości regionów wydają się kluczowym konceptem wartym głębszej refleksji. Stwierdzenie to jest w znacznym zakresie poparte doświadczeniem prowadzonych - w ciągu kilkudziesięciu już lat - studiów strategicznych, foresightowych i projektowych oraz prac eksperckich.

Wyzwania przyszłości są, w przyjętym w tym opracowaniu sensie i ujęciu, wyrazem podzielanej postawy filozoficznej i szerszej długofalowej perspektywy (rys. 1), zgodnie z którą:

- o przyszłości warto myśleć w kategorii wyzwań,

- przyszłość kreuje się, pamiętając o jej wielorakości,

- do przyszłości trzeba zawczasu się przygotować, niejako wyprzedzając czas.

Zgłębianie konceptu wyzwań przyszłości i korzystanie z niego oznacza obranie postawy zarówno preaktywnej, jak i proaktywnej.

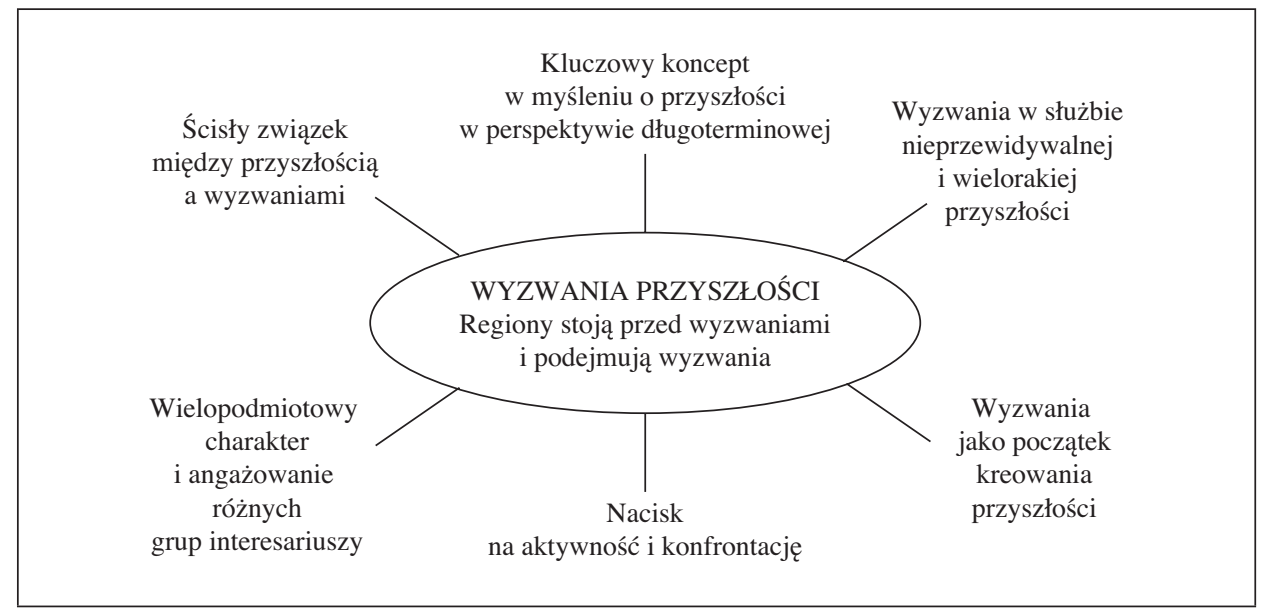

Rys. 1. Wyzwania przyszłości

Źródło: opracowanie własne na podstawie [Les villes... 2011].

Podążając ku przyszłości, kreując ją i budując, wybieramy „drogę bez odwrotu”, a może jeszcze dosadniej - ,drogę bez powrotu”. W tym ostatnim określeniu chodzi nie tylko o pozytywne myślenie, ale przede wszystkim o pełne zaan- 
gażowanie w to, co przed nami, co podejmujemy i chcemy z pełną konsekwencją realizować, korzystając z talentów, wiedzy, wyobraźni i intuicji, a zarazem wykorzystując i niejako pomnażając przez uczenie się posiadany potencjał intelektualny oraz wyróżniające nas atuty i kompetencje.

Wyzwania przyszłości są kluczową ideą w myśleniu o przyszłości i w kreowaniu przyszłości firm i korporacji, w tworzeniu i rozwijaniu globalnych start-upów, w myśleniu o przyszłości i kreowaniu przyszłości miast i regionów, a także w podejmowaniu inicjatyw i innowacji obywatelskich. Posługiwanie się wyzwaniami przyszłości w odniesieniu do rozwoju lokalnego i regionalnego pozwala równolegle na odkrywanie nisz rozwojowych i nowych horyzontów. Ze względu na twórczą nośność konceptu „wyzwania przyszłości” niezbędne jest jego wprowadzenie na stałe do praktycznych studiów foresightowych i analizy strategicznej rozwoju lokalnego i regionalnego.

\section{Przyszłość regionów}

Przyszłość regionów oglądana w perspektywie długoterminowej każe zwrócić szczególną uwagę na ich wewnętrzne układy podmiotowe i zdolności samoorganizacyjne. Region powinien sam od wewnątrz kreować i stopniowo kształtować swoją przyszłość. Region zdolny ukształtować się jako upodmiotowiona przestrzeń może traktować własną przyszłość w kategoriach zobowiązania i odpowiedzialności. Może kreować własną przyszłość, a nie tylko dostosowywać się do ewolucji otoczenia [Parr 2004]. Jest tak nawet w sytuacjach, gdy uwarunkowania zewnętrzne jawią się jako szczególnie niekorzystne i niesprzyjające pożądanym zmianom i procesom rozwojowym.

Podmiotowość regionu zapewniona jest w podstawowym zakresie przez decentralizację funkcji państwa oraz rozwój samorząaności nie tylko na poziomie lokalnym, ale również na poziomie subregionalnym, odpowiednio do specyfiki układów funkcjonalno-przestrzennych danego regionu oraz na poziomie regionalnym. Na poziomie subregionalnym chodzi w pierwszej kolejności o uwzględnienie miejskich obszarów funkcjonalnych, w tym aglomeracji miejskich, które same mogą uruchamiać procesy zarządcze oraz względem których region może prowadzić politykę rozwoju. Decentralizacja funkcji państwa oznacza umieszczenie w regionie zadań publicznych związanych z gospodarką regionu i zapewnieniem wysokiej jakości życia społeczności regionalnej. Region uzyskuje wtedy względną samodzielność w decydowaniu o sposobach realizacji zadań publicznych, a przede wszystkim o kierunkach inwestowania we własny, przez siebie kształtowany rozwój.

Samorządność regionu i w regionie oznacza możność rozwijania różnych form współrządzenia i współzarządzania. Region jest jednostką terytorialną niedo- 
mkniętą i wielopodmiotową. O jego przyszłości decyduje w pierwszej kolejności samorząd regionu. Aktywność samorządu regionu w zakresie polityki rozwoju wymaga uzupełnienia o aktywność prorozwojową interesariuszy biznesowych w regionie oraz zaangażowania się w procesy rozwojowe organizacji sektora obywatelskiego. W ten sposób buduje się stopniowo regionalny governance oparty na podmiotowości i samorządności regionu, którego władza regionalna jest zdolna podjąć funkcję przywództwa strategicznego [Schmidt 2003, Stoper 2014]. Regionalny governance zapewnia także partycypację społeczną i rozwijanie różnych form partnerstwa na rzecz rozwoju: publiczno-prywatnego i publiczno-obywatelskiego. W przypadku braku lub słabości przywództwa regionalnego opartego na samorządzie regionu przebudowie, a w końcu zachwianiu ulega regionalny governance.

Strategiczne myślenie o przyszłości regionów jako podmiotów realizujących funkcje przywództwa strategicznego wymaga podejścia terytorialnego do regionu jako tworu przestrzennego (rys. 2). Regiony są wyodrębnioną częścią przestrzeni narodowej. Każdy region ma swoje specyficzne układy funkcjonalno-przestrzenne, w ramach których stopniowo powstają struktury governance związane z konkretnym terytorium. Podmiotowe widzenie regionu wymaga identyfikacji terytorium lub terytoriów jako miejsc integracji wielu aktywności i działań, budowania czegoś wspólnie, kreowania nowych wartości w wymiarze wspólnotowym, tj. w różnych konfiguracjach podmiotowych głównych interesariuszy sceny regionalnej [Jewtuchowicz 2005].

\begin{tabular}{|c|c|c|}
\hline 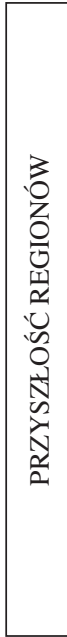 & $\begin{array}{l}\text { Podmiotowość regionów; } \\
\text { decentralizacja } \\
\text { i samorządność regionów } \\
\text { Regiony jako terytoria; } \\
\text { przywództwa regionalne, } \\
\text { integracja społeczna } \\
\text { i tożsamość regionalna } \\
\text { Typy wyzwań i dziedziny } \\
\text { związane z przyszłością } \\
\text { regionów }\end{array}$ & $\begin{array}{l}\text { Przyszłość regionu kształtowana } \\
\text { autonomicznie przez władzę } \\
\text { regionalną i interesariuszy regionu } \\
\text { Skupiska aktywności obywatelskiej } \\
\text { i gospodarczej na rzecz przyszłości } \\
\text { regionu } \\
\text { Wyzwania intelektualne i strategiczne; } \\
\text { wyzwania dotyczące kreatywności } \\
\text { i rozwoju oraz stabilizacji i bezpieczeństwa } \\
\text { w takich dziedzinach, jak: } \\
\text { - przemiany tożsamościowe } \\
\text { - metropolizacja } \\
\text { - specjalizacja } \\
\text { Współrządzenie i współzarządzanie, } \\
\text { partycypacja społeczna, partnerstwa } \\
\text { strategiczne }\end{array}$ \\
\hline
\end{tabular}

Rys. 2. Przyszłość regionów

Źródło: opracowanie własne. 
Dla terytorium właściwe są takie pojęcia, jak: tożsamość, zakorzenienie, zawłaszczanie itp. Terytorium to miejsce solidarności i współpracy. Jest ono stale tworzone i umacniane. Procesy dezintegracyjne mogą rozbijać dotychczasowe terytorium, ale prowadzą także do kreowania nowych terytoriów. O ile kategoria przestrzeni zawiera w sobie otwartość, wolność, nowe horyzonty i tym samym przyszłość, o tyle terytorium może sugerować zamknięcie, zarezerwowanie czegoś dla „swoich”, oderwanie się od nieprzychylnego otoczenia. Kategoria wyzwań przyszłości pozwala unikać takich negatywnych skojarzeń i może przyczynić się do lepszego zrozumienia tego, co dzieje się w otoczeniu, i utrzymywania łączności oraz dynamicznej równowagi z otoczeniem.

Kategoria wyzwań przyszłości dobrze wpisuje się w logikę myślenia strategicznego o przyszłości i kreowania przyszłości. Wyzwania można traktować jako pewne punkty ciężkości, skupiające procesy myślenia o przyszłości na rzeczach najistotniejszych. Zgodnie z przyjętym w tym opracowaniu układem metodycznym można mówić o wyzwaniach przyszłości regionów w dwojakim znaczeniu, tj. jako o: 1) wyzwaniach intelektualnych odnoszących się do odczytania i zrozumienia tego, co dzieje się w otoczeniu i z czym dany region będzie musiał się zmierzyć, ponieważ nie uniknie zderzenia z nową rzeczywistością; 2) wyzwaniach strategicznych wypracowanych w procesie lub procesach zarządzania strategicznego regionem i w regionie, stosownie do ukształtowanego regionalnego governance.

Wyzwania intelektualne pojawiają się jako zwieńczenie, synteza eksperckich diagnoz na temat zmian cywilizacyjno-kulturowych w otoczeniu regionu, zmian i przełomowych innowacji technologicznych ważnych dla przyszłości gospodarki regionu. Jawią się jako „odczytywane znaki czasu”, dotyczące otoczenia globalnego i megatrendów pojawiających się w makrootoczeniu, jak i otoczeniu specyficznym dla każdego regionu. Są one syntezą zbiorowej wiedzy o tym, co nowe, inne niż dotychczas, co otwiera nowe możliwości lub niesie niebezpieczne zmiany, kryzysy i załamania, na które region powinien znaleźć strategiczną odpowiedź. W procesie planowania strategicznego pojawiają się one jako wynik diagnoz eksperckich różnych zespołów specjalistów reprezentujących różne rodzaje wiedzy użytecznej w zarządzaniu regionem [Les villes... 2011]. Wyzwania intelektualne wiążą się bezpośrednio z filozofią i metodologią studiów foresightowych. Można je umieścić na samym początku cyklu zarządzania strategicznego.

Wyzwania strategiczne są integralną częścią procesu zarządzania strategicznego, w tym budowania strategii rozwoju. Wiążą się one bezpośrednio z wizją rozwoju regionu. Można je uznać za element wizji, która jest adresowana do konkretnego podmiotu regionalnego i jego partnerów strategicznych. Wyzwania strategiczne wskazują na najważniejsze procesy i zdarzenia, które w przyszłości pojawią się w otoczeniu danego regionu i co do których region będzie zmuszony zająć stanowisko. Przyjmują formę zobowiązań własnych, autonomicznych przy- 
wództwa regionalnego, dotyczących sprostania temu wszystkiemu, co w otoczeniu regionu można uznać za istotne z punktu widzenia jego przyszłości.

Obydwa typy wyzwań, tj. wyzwania intelektualne i wyzwania strategiczne, odnoszą się do kilku istotnych sfer związanych z przyszłością regionów. Tymi sferami są:

- przemiany tożsamościowe regionów,

- metropolizacja regionów,

- specjalizacja regionalna.

Przemiany tożsamościowe $\mathrm{w}$ przypadku regionów związane są z trendami cywilizacyjno-kulturowymi, w ramach których pojawiają się zjawiska o dużej nieciągłości. Mogą to być z jednej strony załamania, rewolucje, katastrofy, a $\mathrm{z}$ drugiej - zjawiska nowe, rokujące w dalszej przyszłości pozytywne zmiany w regionie. Metropolizacja regionów może być postrzegana jako nieuchronny proces globalizacji przestrzeni zurbanizowanych. Dla jednych regionów pojawia się wyzwanie bycia regionem metropolitalnym, dla innych zaś konieczność wpisania się w procesy metropolizacji dziejące się „obok”, aby osiągnąć maksymalne korzyści własne. Specjalizacja regionalna jawi się w konsekwencji jako sfera wynikowa decyzji strategicznych. Region staje przed nieuchronnym wyzwaniem określenia swojego miejsce w grupie regionów konkurencyjnych.

W ramach wyzwań strategicznych warto zwrócić uwagę na podział na wyzwania kreatywności i rozwoju i wyzwania stabilizacji i bezpieczeństwa. Wyzwania kreatywności i rozwoju pojawiają się w sytuacjach, kiedy region przyjmuje ofensywną postawę strategiczną; czuje się na siłach wchodzić na nowe ścieżki rozwojowe, realizować „wielkie pchnięcie” ku nowej przyszłości. Wyzwania stabilizacji i bezpieczeństwa pojawiają się, po pierwsze, jako uzupełnienie wyzwań kreatywności i rozwoju. Dotyczą uporządkowania tego wszystkiego, co zostało po przeszłości (np. wyzwania rewitalizacyjne). Po drugie, wyzwania stabilizacji i bezpieczeństwa mogą stanowić wyzwania strategiczne. Jest tak w sytuacjach, kiedy regionu nie stać na kreowanie ambitnej przyszłości, kiedy trzeba skupić się na dostosowaniu do niekorzystnych zjawisk w otoczeniu.

\section{Wizje regionów w interakcji z wyzwaniami przyszłości}

Wyzwania przyszłości i myślenie o przyszłości regionów łączą ze sobą wizje regionów. Kreowanie wizji przez regiony odbywa się współcześnie coraz częściej w oparciu o studia foresightowe (prospektywne), w szczególności służy temu foresight strategiczny [Making Europe... 2014]. Regionalny foresight strategiczny należy w tym opracowaniu rozumieć jako ukierunkowany przez wartości i na wartości proces angażujący zbiorową wyobraźnię i wiedzę wszystkich ważnych uczestników sceny regionalnej [Klasik, Biniecki i Ochojski 2014]. 
Wizja przyszłości konkretnego regionu jest zatem opisem pożądanego obrazu jego przyszłości i ciągów pożądanych zmian prowadzących do urzeczywistnienia tego obrazu. Istnieją różne propozycje wyrażania treści wizji. W podstawowym ujęciu kreowanie wizji sprowadza się najczęściej do określenia przyszłego, pożądanego wizerunku i pozycji regionu w relacji z jego otoczeniem. W bardziej rozwiniętej postaci wizje regionów mogą być oparte na trójczłonowej formule, obejmującej:

- fundamenty, w tym potencjał regionu, na którym można oprzeć przyszłe procesy rozwojowe,

- kluczową działalność definiującą podtrzymywane i nowo tworzone specjalności regionalne,

- konkurencyjność oferty wartości rynkowych i nierynkowych spełniających oczekiwania odbiorców.

Wizje rozwoju regionów powinny być traktowane w pierwszym etapie jako autonomicznie formułowane koncepcje rozwoju endogennego poddawane w następnym etapie procedurze testowania wielorakimi scenariuszami uwarunkowań zewnętrznych ewolucji otoczenia krajowego i międzynarodowego.

W każdej z zaprezentowanych formuł wyrażania treści i zawartości wizji regionów warto przywołać istotę strategicznego myślenia w odniesieniu do rozwoju regionów, w myśl której:

- tworzenie wizji ukierunkowane jest przez wartości i na wartości,

- wizje regionów kształtuje się w relacji do wartości oczekiwanych przez ich odbiorców,

- od przywódców regionalnych oczekuje się wizjonerskich zdolności i podejmowania inicjatywy strategicznej,

- tworzenie wizji regionu wymaga angażowania zbiorowej wyobraźni i wiedzy uczestników sceny regionalnej.

Definiowane i formatowane w ten sposób wizje regionów mogą otwierać na myślenie w kategorii wyzwań rozumianych jako wyzwania strategiczne. W efekcie otrzymuje się wizje regionów zawierające oprócz wyzwań orientacje i zasady strategiczne profilujące ich przyszły rozwój [Klasik i Biniecki 2015].

Punktem wyjścia do całościowego ujęcia wizji regionów w interakcji z wyzwaniami przyszłości następuje przy użyciu dwojakiego typu relacji: relacji typu backwards oraz relacji typu forwards. Relacje „,do tyłu” uruchamia prospektywna, zewnętrzna diagnoza i ewaluacja obecnej sytuacji regionów. Jest to wielowymiarowa i wielotematyczna diagnoza i ewaluacja konkretnego regionu realizowana przez specjalistów różnych dziedzin i dyscyplin przy współpracy i znaczącym udziale zewnętrznych konsultantów. Ewaluacja i diagnoza stanu regionów z wielu różnorodnych perspektyw i w powiązaniu ze światem zewnętrznym prowadzi do ustalenia wyzwań przyszłości, które w tym opracowaniu określa się mianem wyzwań 
intelektualnych (rys. 3). Ten typ wyzwań przyszłości postrzeganych przez każdy konkretny region plasuje się w sferze specyficznych dla niego przemian kulturowych i cywilizacyjnych. Regiony stoją przed wyzwaniami intelektualnymi o charakterze społeczno-kulturowym i naukowo-technologicznym. Niedostrzeganie tego typu wyzwań lub ich niedocenianie jako istotnych okoliczności w autonomicznym formułowaniu koncepcji rozwoju endogennego obciąża wizje regionu jeszcze w zarodku.

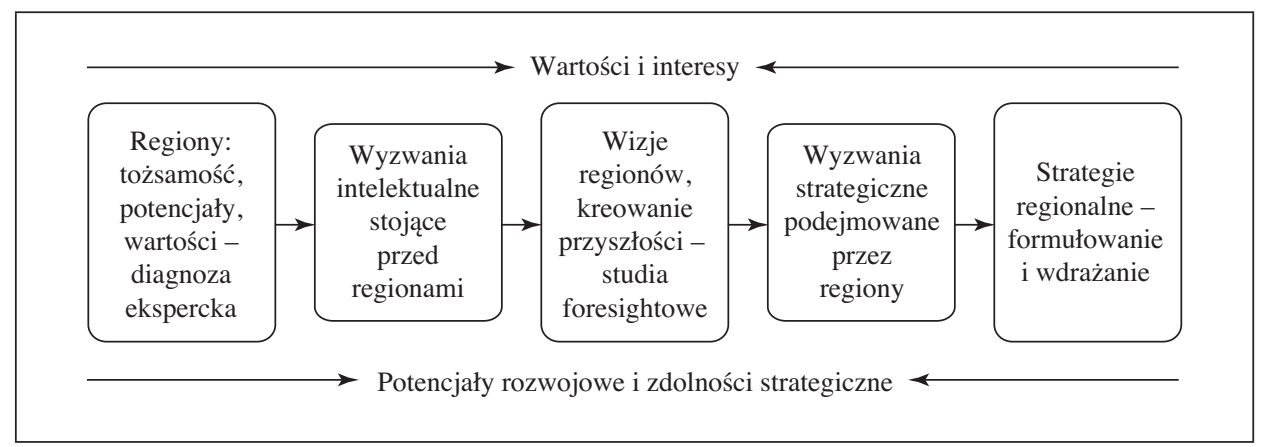

Rys. 3. Wizje regionów w interakcji z wyzwaniami przyszłości

Źródło: opracowanie własne na podstawie [Klasik 2002].

Wizje regionów w interakcji typu „w przód” odnoszą się do uruchomienia analizy strategicznej i formułowania strategii regionów. To wizje regionów stanowią fundament definiowania „w przód” wyzwań strategicznych. Wyzwania strategiczne stanowią praktyczną podstawę i przesłankę realistycznego określania celów strategicznych regionów. Prowadzą do ustalenia, co, ile i do kiedy chcemy wspólnie w regionie osiągnąć. Wyzwania strategiczne stają się zarazem zewnętrznymi czynnikami regionalnej analizy strategicznej. Leżą one u podstaw formułowania dwojakiego typu strategii. Powiązanie ze sobą atutów wyróżniających i wyzwań strategicznych prowadzi do obrania opcji typu push, ,idź do przodu”, inwestuj i rozwijaj się. Natomiast sprzężenie ze sobą drastycznych deficytów występujących w regionie, blokujących urzeczywistnianie wizji regionu i osiąganie celów strategicznych, z wyzwaniami strategicznymi pozwala na sformułowanie opcji typu pull, ,,podciągaj się w górę”, walcz o swoją przyszłość, usuwając po drodze bariery rozwoju.

\section{Sceny regionalne w grze o przyszłość regionów}

Przyszłość regionów rozgrywa się w ramach różnych mechanizmów, przez które władze regionalne oraz interesariusze sceny regionalnej projektują i realizują 
swoje strategie rozwojowe, zawierają różne koalicje, prowadzą debaty i negocjacje, podejmują własne decyzje inwestycyjno-lokalizacyjne. Można wyróżnić trzy mechanizmy w grze o przyszłość regionu:

- mechanizm rynkowy,

- mechanizm regulacyjny/polityki rozwoju,

- mechanizm społecznościowy.

Mechanizm rynkowy jest podstawowym mechanizmem regulującym procesy rozwojowe $\mathrm{w}$ przestrzeni regionu. W relacjach rynkowych zarówno władze publiczne, jak i samodzielne podmioty gospodarcze wchodzą w interakcje ze swoimi kontrahentami i realizują wiele projektów rozwojowych, które mają znaczenie dla przyszłości regionu. Rynki, w ramach których funkcjonuje dany region, pozwalają na wybory inwestycyjno-lokalizacyjne interesariuszy regionu, które w finalnym rozrachunku przynoszą pozytywne, a czasami negatywne skutki dla regionu. Układ sił różnych interesariuszy regionu ujawniany przez zachowania rynkowe staje się częścią składową regionalnego governance.

Mechanizm regulacyjny związany jest z różnymi formami ingerencji w rozwój regionów. Chodzi głównie o politykę regionalną szczebla krajowego i politykę rozwoju regionu prowadzoną przez władze w regionie. Polityka rozwoju jest formą ingerencji w procesy rozwojowe nałożoną na mechanizm rynkowy. Podstawowym podmiotem polityki rozwoju w regionie jest władza samorządowa regionu. Przysługuje jej inicjatywa strategiczna zarówno w rozumieniu wykreowania strategicznej koncepcji rozwoju regionu, jak i uruchomienia debaty publicznej w gronie najważniejszych interesariuszy decydujących o przyszłości regionu. W konsekwencji upublicznienia debaty nad przyszłością regionu może rozpocząć się proces zawiązywania koalicji i partnerstw, które doprowadzą do generowania projektów rozwojowych i/lub skorygują decyzje inwestycyjno-lokalizacyjne strategicznych interesariuszy regionu. Gra o przyszłość regionu prowadzona w ramach mechanizmu regulacyjnego polityki rozwoju, tj. na rzecz realizacji strategii rozwoju regionu sformułowanej przez władze regionalne, zależy od siły decyzyjnej i środków finansowych, jakimi władze regionu mogą dysponować. W przypadku słabości strategicznego przywództwa regionu maleje też skłonność wchodzenia interesariuszy do gry o rozwój regionu.

Mechanizm społecznościowy oparty na sile i zaangażowaniu sektora obywatelskiego należy traktować jako równoprawny. Moc sprawcza sektora obywatelskiego i jego organizacji zależy od poziomu aktywności obywatelskiej. Może przejawiać się w formie:

- formułowania i promocji nowych idei rozwojowych,

- budzenia aktywności obywatelskiej na rzecz postaw zaradczych, samoorganizacji i obywatelskich inicjatyw rozwojowych, 
- kontroli społecznej zachowań grup politycznych oraz strategicznych interesariuszy biznesowych realizujących ukryte zamiary sprzeczne z dobrem publicznym $\mathrm{i}$ interesem regionalnym.

Mechanizm społecznościowy jest niezbędnym dopełnieniem mechanizmu rynkowego i mechanizmu regulacyjnego. Bez aktywności obywatelskiej wpisanej na stałe w grę o przyszłość regionu wzajemne relacje władzy publicznej i biznesu, w tym inicjatywy projektowe partnerstwa publiczno-prywatnego, będą słabo zrozumiałe dla różnych środowisk społecznych regionu i narażone na zarzuty dominacji interesów partykularnych nad dobrem publicznym. Mechanizm społecznościowy dopełnia również regionalny governance.

Kategoria wyzwań przyszłości zarówno w postaci wyzwań intelektualnych, jak i wyzwań strategicznych ułatwia integrację trzech wyżej wspomnianych mechanizmów, ważnych w grze o przyszłość regionów. Ułatwia ona prowadzenie debat nad przyszłością regionu: koncentruje debaty wokół spraw najważniejszych, definiuje język komunikacji między interesariuszami regionu, wprowadza element emocji i zaangażowania się na rzecz lepszej przyszłości swojego regionu.

Gra o przyszłość regionu rozgrywa się na różnych scenach. Prawdopodobieństwo pojawienia się jednej centralnej sceny w regionie jest niewielkie. Trzeba raczej widzieć różne sceny, na których ujawniają się wszystkie trzy mechanizmy rozwojowe. Powinnością władzy regionalnej jest wprowadzić do gry najważniejszych interesariuszy, dających się określić jako interesariusze strategiczni. Strategiczność wyznaczają siła wpływu danego interesariusza na procesy rozwojowe w regionie, która może być dodatnia lub ujemna, oraz chęć i poziom zaangażowania w poszczególnych interesariuszy w sprawy regionalne.

Zastosowanie metody mapowania interesariuszy w grze o przyszłość regionów pozwala wyróżnić cztery grupy interesariuszy (rys. 4). Są to:

- najważniejsi gracze, których cechuje silny realny wpływ na rozwój regionu oraz wysoki poziom zaangażowania i przyczynianie się swymi decyzjami i działaniami do tworzenia dobrych perspektyw rozwojowych regionu,

- potencjalni sprzymierzeńcy, którzy wykazują wysoki poziom zaangażowania, gdy chodzi o sprawy regionu, i jednocześnie niski realny wpływ na procesy rozwojowe toczące się na jego obszarze,

- potencjalni oponenci, czyli grupy biznesowe, polityczne i inne, których potencjalny wpływ na rozwój regionu może okazać się znaczący, jeśli wykażą się niezrozumieniem lub dystansowaniem się wobec sytuacji regionu,

- niezainteresowani regionem, którzy przyjmują postawę rezydentów nieobecnych i niewchodzących w kontakty i trwałe relacje z władzą regionalną i innymi interesariuszami. 


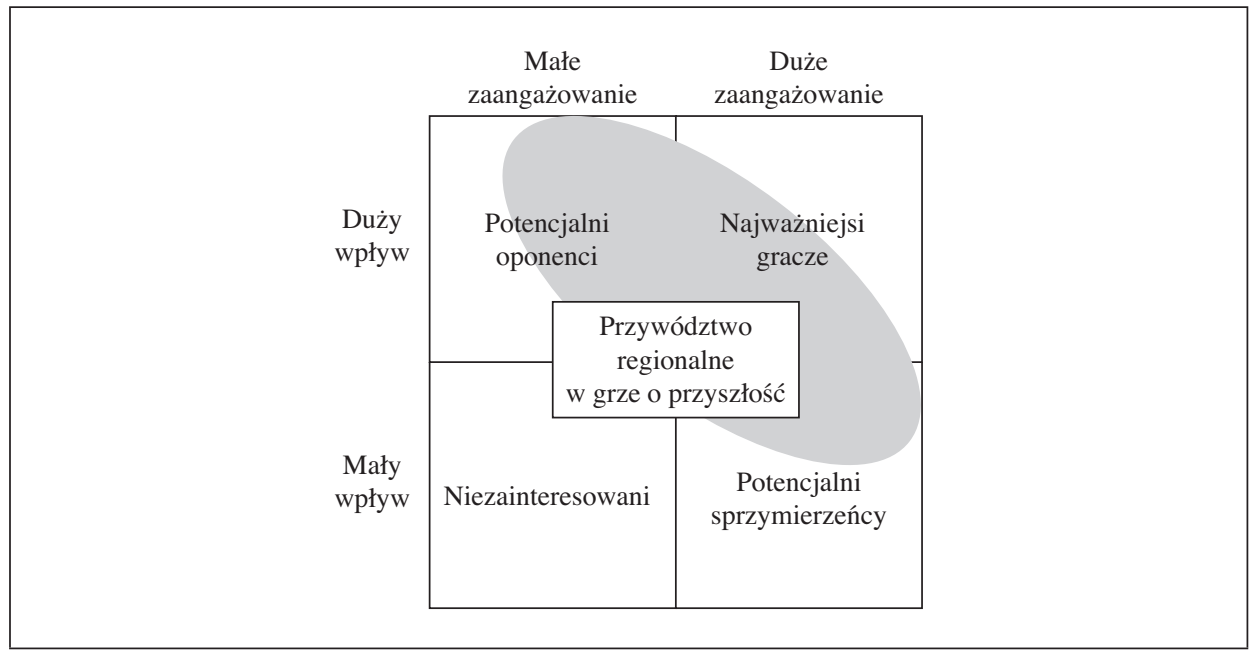

Rys. 4. Interesariusze w grze o przyszłość regionów

Źródło: opracowanie własne na podstawie [Johnson, Scholes i Whittington 2010].

Ujęte na mapie interesariuszy przywództwo regionalne w grze o przyszłość regionu powinna cechować inicjatywa strategiczna w relacji z wszystkimi grupami interesariuszy działającymi na scenach regionu. Szczególnego znaczenia wydają się nabierać relacje z potencjalnymi oponentami ze względu na możliwość ich pozyskania do współpracy.

W obrębie tych dwóch zmiennych - wpływu i zaangażowania, toczy się gra o przyszłość regionu, w której przeplatają się wartości ważne dla regionu oraz różne interesy indywidualne i grupowe. Można przyjąć, że władza regionalna jest strażnikiem wartości ważnych dla regionu (wartości regionu). Przysługuje jej prawo definiowania tych wartości i przedstawiania ich w konwencji dobra wspólnego czy w formie bardziej uszczegółowionej - w konwencji interesu regionalnego. Ponadto transparentność działania władz publicznych wymaga, aby władze regionu ujawniały sposób definiowania powyższych kategorii. Interesariuszom regionu przysługuje prawo do realizowania własnych interesów. Każdy interesariusz z sektora biznesu czy sektora obywatelskiego ma swoje wartości, których nie musi ujawniać. Może komunikować się z innymi, w tym z władzami regionu, za pomocą parametrów opisujących poziom oczekiwania realizacji jego interesów. Można przyjąć, że władze regionu działają według reguły „wartości przed interesami”, zaś interesariusze regionu według reguły „,interesy przed wartościami”. Zbiór interesariuszy regionu jest mocno zróżnicowany, a tym samym relacje interesy-wartości mogą układać się odmiennie w przypadku interesariuszy biznesowych i sektora obywatelskiego. 


\section{Konkluzje}

Znaczenie konceptu wyzwań przejawia się w procesie myślenia i kreowania przyszłości regionów na kilka sposobów. Można je skrótowo ująć w postaci następujących wartości:

- diagnostycznej,

- intelektualnej,

- kreacyjnej,

- integracyjnej.

Wartość diagnostyczna wyzwań przyszłości uwidacznia się w umiejętności wykorzystywania interdyscyplinarnej wiedzy kreowanej w ramach studiów foresightowych. Chodzi tu o rodzącą się wiedzę, uzyskiwaną w wyniku metodycznie uporządkowanego, zbiorowego myślenia o przyszłości z wykorzystaniem każdej informacji pochodzącej od specjalistów i ekspertów zaproszonych do studiów foresightowych. Wartość diagnostyczna wyzwań wyraża się w pewnego rodzaju biegłości i zwięzłości odczytania wielu rozbudowanych diagnoz eksperckich opartych na szczegółowych analizach i sporządzonych w hermetycznym języku. Wyzwania pozwalają w takiej sytuacji uchwycić to, co najistotniejsze w myśleniu o przyszłości. Z jednej strony, wyznaczają profil ekspertów dobieranych do studiów foresightowych. Z drugiej strony, pozwalają z gąszczu użytecznych informacji wybrać to, co ogniskuje myślenie o przyszłych decyzjach i będzie motywować do działania.

Wartość intelektualna wyzwań pojawia się na styku myślenia foresightowego o przyszłości regionów oraz osiągnięć nauki i sztuki, które mogą mieć wpływ na trajektorie rozwojowe regionów. Intelektualność konceptu wyzwań przyszłości polega na tym, że pozwalają one na utrzymywanie stałej łączności przywództwa strategicznego regionu ze środowiskami intelektualistów zainteresowanych przełomowymi zmianami i kreowaniem przyszłości. Osiągnięcia nauki i sztuki nie są łatwe do interpretowania w procesie kreowania wizji przyszłości, a dalej - w myśleniu strategicznym władz regionalnych. Wymagają klucza interpretacyjnego w postaci wyzwań, tak aby w sposób praktyczny można było przejść do kreowania przyszłości regionów.

Misja kreowania przyszłości wymaga postaw kreatywnych od podmiotu regionalnego i wszystkich ważnych uczestników sceny regionalnej. Wymaga także stałego koncentrowania się na rzeczach najważniejszych w połączeniu z umiejętnością rezygnacji z tego, co wprawdzie ważne, ale nie najważniejsze. Co więcej, z istoty wyzwań wynika jednoznacznie, że misja kreowania przyszłości zakłada otwarcie długoterminowej perspektywy myślowej. Jej rozwinięcie w trakcie tworzenia autonomicznych wizji przyszłości regionów jest uprawnione, jeśli dokona się uprzedniego ustalenia ograniczonych co do liczby obszarów tematycz- 
nych punktów ciężkości. Dla urealnienia wizji rozwojowych regionów niezbędne jest ich testowanie w oparciu o scenariusze uwarunkowań zewnętrznych uwzględniające megatrendy, punkty zwrotne i przełomy oraz nieoczekiwane wydarzenia.

Decyzje strategiczne kształtujące przyszłość regionów wymagają współdziałania podmiotu regionalnego i ważnych uczestników sceny regionalnej. Zakłada to zaprojektowanie takiego regionalnego governance, który umożliwia podejmowanie inicjatyw wdrażających decyzje strategiczne przez władze regionalne. $\mathrm{Z}$ drugiej strony pojawia się oczekiwanie władz regionalnych, aby uczestnicy scen regionalnych włączyli się w procesy rozwojowe regionów. Kategoria wyzwań strategicznych wykorzystana w procesie podejmowania decyzji strategicznych objawia swoją wartość integracyjną przez możliwość budowania systemów motywacyjnych oraz zawiązywania akcji regionalnych skutkujących rozwojem społecznie akceptowalnym.

\section{Literatura}

Jewtuchowicz A. [2005], Terytorium i współczesne dylematy jego rozwoju, Wydawnictwo Uniwersytetu Łódzkiego, Łódź.

Johnson W.J., Scholes K., Whittington R. [2010], Podstawy strategii, PWE, Warszawa.

Klasik A. [2002], Strategie regionalne. Formułowanie i wdrażanie w życie, Wydawnictwo Akademii Ekonomicznej w Katowicach, Katowice.

Klasik A., Biniecki J. [2015], Strategiczna koncepcja polityki użytkowania terenów w regionie, na przykładzie woj. ślaskiego [w:] Gospodarowanie przestrzenia miast i regionów, Studia Komitetu Przestrzennego Zagospodarowania Kraju PAN, t. CLXI, Warszawa.

Klasik A., Biniecki J., Ochojski A. [2014], Metropolitalny foresight strategiczny. Metodologia i studium przypadku, Studia Komitetu Przestrzennego Zagospodarowania Kraju PAN, t. CLX, Warszawa.

Klasik A., Kuźnik F. [2013], Foresight Studies in Facilitating the Development and Management of a Region (Practical Experience in Silesia) [w:] Programming Regional Development in Poland. Theory and Practice, eds T. Kudłacz, D. Woźniak, Studia Regionalia, Komitet Przestrzennego Zagospodarowania Kraju PAN, nr 35, Warszawa.

Les villes de demain. Defis, visions et perspektives [2011], UE, Bruxelles.

Making Europe Open and Polycentric. Vision and Scenarios for the European Territory towards 2050 [2014], ESPON, Luxembourg.

Parr J. [2004], The Polycentric Urban Region: A Closer Inspection, „Regional Studies”, vol. 38, nr 3, May, https://doi.org/10.1080/003434042000211114.

Schmitt P. [2003], Planning for Polycentricity in European Metropolitan Areas - Challenges, Expectations and Practices, „Planning Practice and Research”, vol. 28, $\mathrm{nr} 4$, https://doi.org/10.1080/02697459.2013.780570.

Stownik języka polskiego [1985], t. 3, PWN, Warszawa.

Storper M. [2014], Governing the Large Metropolis, „Territory, Politics, Governance”, vol. 2, nr 2, https://doi.org/10.1080/21622671.2014.919874. 


\section{Regions and the Challenges of the Future}

(Abstract)

In this article, we locate the notion of "challenges of the future" in the processes targeting the creation of regional futures. The paper contains methodological reflection upon the positioning of challenges in analysing and creating the future. It shows the central position of the "challenges of the future" in strategy development and regional growth management. Their application in diagnosing problems and in the conducting of foresight studies and strategy development is described on the basis of the authors' expertise.

Keywords: challenges of the future, regional futures, regional visions, challenging regional futures. 